\title{
A Brief Anatomy of Offensive Imagery
}

Jojada Verrips

\author{
Blasphemy and Obscenity are, \\ just like Beauty, \\ in the Eye of the Beholder.
}

\begin{abstract}
Warburg was aware that the self, always to be newly formed and protected, can receive support, but also injuries, from pictures. That the vitality of the picture, with its possibility to >do something to someone or something $\triangleleft$, also possesses the potency for injury $[\ldots]^{2}$
\end{abstract}

\section{Introduction}

We live in an era in which we are confronted with a mega-flood of images as an immediate consequence of the rapid development of highly advanced technological means to produce, reproduce, and globally distribute them. This is certainly not an original observation; it has been made by numerous scholars. ${ }^{3}$ In general, people react in three ways to the images they confront in books (normal or e-books), cinemas, computers, iPads and iPhones, journals, newspapers and TV, and museums and public space, to mention just a few of the media and places in which they pop up: in a neutral, a positive, or a negative way. That is, they remain indifferent toward the images, they like them, or they dislike them. This essay does not give center stage to the images that leave people undisturbed or the ones that move them in a positive sense, but to those that appall, disrupt, hurt, shake, shock, and unsettle beholders, images that call forth disgust, anger, aggression, and in their wake often the wish to make them immediately disappear from our view and that of others, if need be by cutting them into pieces and/or burning them. ${ }^{4}$ The desire to get rid of disgusting and loathsome images, as if they were pernicious and polluting »individuals«, and to purify the world 
does not greatly differ from the wish, as often crops up in wars, to let certain individuals, perceived as despicable and therefore unwanted »objects, « disappear from the surface of the earth. This is a reaction that shows a strong family resemblance to making a religious sacrifice to get rid of polluting elements (both objects and subjects) as described and analyzed by Hubert and Mauss.5 In this connection, the following remark by Bruno Latour on what the exhibition Iconoclash in 2002 was all about is striking: »It attempts to suspend the urge to destroy images, requires us to pause for a moment; to leave the hammer to rest. It prays for an angel to come and arrest our sarificial arm holding the sacrificial knife ready to cut the sacrificial lamb's throat. ${ }^{6}$

Against this background, it is in fact rather surprising that the insight that images »want « something from us and/or »do« something with us, as if they were a particular kind of living beings, is presented time and again as a new discovery or insight, for instance by sociologists and art historians. In this connection, book titles like What Do Pictures Want? The Lives and Loves of Images and How Images Think, ${ }^{8}$ as well as the popularity of theories in which things or objects play a crucial role (see Kruse in this volume), such as Latour's Actor Network Theory (ANT) and Bredekamp's Theorie des Bildakts, ${ }^{9}$ are revealing. Yes, images »do « something with people, generate something in them, for instance, emotions that move between the poles of positive and negative. ${ }^{10}$ What I deem more important than to establish this once more is to take a different road by paying attention to the burning question of what kind of images preeminently do so in a negative way and why? Or, phrased differently, what sort of pictures possess the power to generate bewilderment, disgust, and disruption over and over again and to stimulate people to undertake action directed 
toward their disappearance through censorship or, worse, destruction? If one casts a glance at, for instance, the great and seemingly increasing number of scandals triggered by images in the Western world since the mid-1 $9^{\text {th }}$ century, one can easily get the impression that the variation in imagery capable of shocking and hurting people is endless.

The main goals of this article are as follows: First, I want to make it clear that there seems to be a system in the »madness « or chaos, by showing that one can distinguish a limited number of genres (and subgenres) of imagery that repeatedly function as neuralgic points and sources of hot-headed, impetuous, and sometimes violent and iconoclastic reactions on the part of certain groups and categories of people who feel offended and attacked by the producers of these genres, the artists. "I Second, I will examine the nature and dynamic of the sociological figuration one has to take into consideration to develop a better understanding of the ways allegedly disgusting images can trigger all kinds of negative, even destructive developments in the social realm on a micro- as well as on a macro-level. Third, I will succinctly present a tentative perspective (or hypothesis) on the background of or underlying reasons for the often aggressive reactions to the imagery created by a broad range of artists.

Some authors are of the opinion that the genesis or rise of so-called shock art and imagery is a rather recent one. Renée Steenbergen, for instance, wrote in the journal CHIQ in 1999: »Rape and mutilation, porno and murder, pop up strikingly often in contemporary painting and sculpture. Shock art is the latest hype in the world of the arts. ${ }^{12}$ She illustrated her article with a provocative photograph titled Happiness is bere to stay by the Dutch photographer Cornelie Tollens that shows a mouth with a penis instead of a tongue. Steenbergen appar- 
ently did not seriously study the fabrication of shocking (artistic) imagery that, long before the 1990s, triggered controversies and that particular categories of people deemed scandalous and censurable, or she would not have written $\gg$ the latest hype. "As a matter of fact, scandals and upheaval over works of art and other imagery have a much longer history in the Western world and can be traced back far before the middle of the $19^{\text {th }}$ century. ${ }^{13}$ Though it might be interesting and relevant to deal with scandals in the distant past, in this essay I will put the spotlight on (artistic) imagery deemed scandalous and therefore fit for censorship or worse from 1850 until the present.

In the second half of the $19^{\text {th }}$ century, there were a number of scandals and controversies, three of which I want to briefly sketch here because in my view they represent prototypical cases of what has been considered scandalous imagery ever since, not only in the so-called Western world, ${ }^{\mathrm{It}}$ but also and to an increasing degree in the world as a whole; this is a direct consequence of the rapid globalization of the production, circulation, distribution, and consumption of art and other imagery. In spite of this development, the emphasis in this essay will be on scandals about controversial imagery produced in the West, which in some cases (take that of the Muhammad cartoons) also caused as much (or even more) upheaval on a global scale. In recent decades, across our ever more entangled world, we hear more and more about scandals triggered by (artistic) imagery deemed to be disgusting and therefore worthy of being banned or destroyed (see Monica Juneja in this volume). 


\section{Prototypical cases}

The first scandal I want to put on center stage here occurred in 1859, when the French zoologist and sculptor Emmanuel Frémiet wanted the Salon in Paris to exhibit a very realistic sculpture of a gorilla carrying off a woman (see caption Fig. I). At first, the members of the jury did not want to accept this provocative piece of art because they found it too shocking for several reasons, including the possibility to interpret it pornographically; but finally they agreed to its exposition in a specific room and behind a green curtain. »The terrifying representation got a pornographic place and at the same time stood at the center of attention, ${ }^{15}$ though not for long, for angry Belgian laborers knocked it to pieces. Maybe they disliked it for the same reason as Baudelaire, who wrote extensively about Frémiet's creation. The poet, like many critics, interpreted the sculpture as a prelude to the rape of a woman by an appalling animal, although Frémiet explicitly carved »Gorille femelle« on it! Baudelaire rejected it with the following words: »Such themes truly are not fit for such a mature talent, and the jury was right to refuse this ugly and dramatic group of figures. $\ll^{16}$ Be that as it may, the sculpture caused a great scandal. And that happened again in I888, when Frémiet exhibited a new version (Fig. I), this time not in plaster but in bronze, at the (Third) International Art Exhibition in Munich, where it »elicited fascination and repulsion from the crowds as they entered the main exhibition hall.« ${ }^{17}$ Whereas the artist in 1859 apparently wanted to prevent the public from thinking about a »mésalliance of the ape in the statue, he did not do this in the second version, which gave ample room for fantasies about such a liaison. 


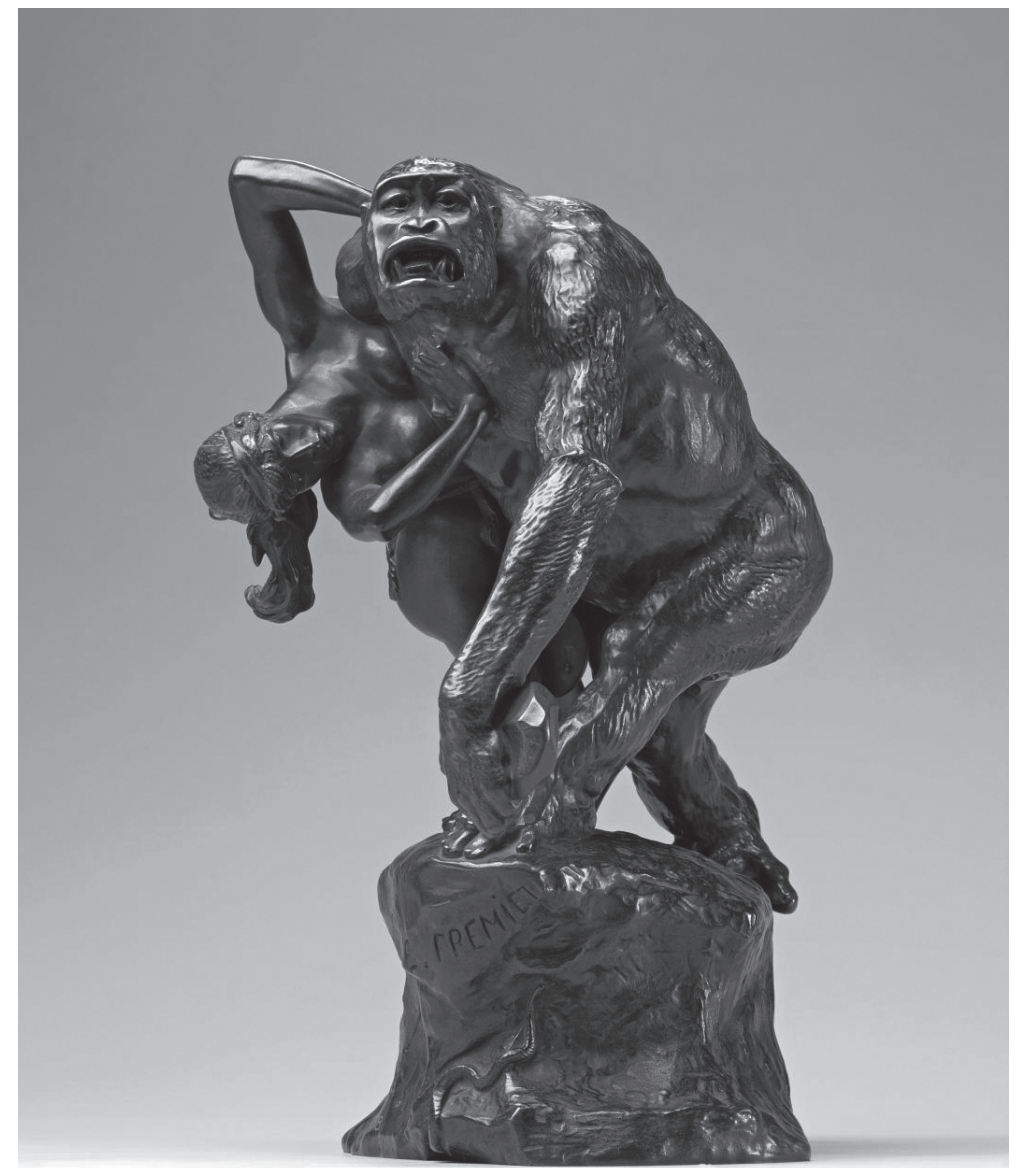

[FIG. 1]

Emmanuel Frémiet: Gorilla

Carrying off a Woman, 1888,

National Gallery of Victoria,

Melbourne 
It is possible that the popularity of Darwin's theory of evolution published in the same year and the fact that this theory stimulated certain scholars to explicitly speculate about the possibility of cross-species sex formed part of the background of Frémiet's decision not to mention the sex of the gorilla ${ }^{18}$

The second scandal in the second half of the $19^{\text {th }}$ century that I want to mention was triggered by Max Liebermann's painting Der zwölfjäbrige Jesus im Tempel, exhibited eleven years earlier at the International Art Exhibition in Munich. Several, mostly Roman Catholic anti-Semitic critics, regarded this work as blasphemous, because Liebermann, who was Jewish, »had dared to publicly throw in the teeth of his fellow Christian citizens such a derision of their Savior « by having painted him as »the ugliest, cheekiest Jewish boy one can imagine. ${ }^{19}$ The uproar was so great that Liebermann decided to repaint Jesus and refrain from producing biblical scenes for at least thirty years. The case was even discussed in the Bavarian Parliament, where a delegate proposed to cancel the promised financial support for the exposition. The threat by New York Mayor Rudolph Giuliani in 1999 to withdraw a seven million-dollar subsidy from the Brooklyn Museum of Modern Art if it did not remove Chris Ofili's painting The Holy Virgin Mary was thus not very original, just an example of »'histoire se repète.« Liebermann was not the only artist to alter a painting; in I891, after his work The Crucifixion had triggered a scandal because it showed Jesus' private parts too realistically, Max Klinger also accommodated his critics.

The third and last scandal in the second half of the $19^{\text {th }}$ century I want to refer to arose over Hermione von Preuschen's allegorical painting Mors Imperator. In 1887 , it was rejected by the jury of the Berlin Academy exhibition, probably because »it made disturbing allusions to the deteriorating condition 
of William I, who died six months later, as well as to the crown prince, who was suffering from cancer. ${ }^{20}$ Von Preuschen decided thereupon to exhibit the painting herself in an exposition hall in Berlin and invited the public through newspaper ads to come and see her »scandalous« work.

\section{A brief anatomy, or the first triangle}

I will now try to elaborate my assertion that the three briefly sketched scandals are prototypical cases par excellence of what is perceived to be scandalous art until now. The imagery presented by Frémiet, Liebermann, and Von Preuschen triggered so much negative response because particular (groups of) persons perceived it as transgressing what they deemed acceptable in the following three crucial, sociocultural realms: I) sexuality (Eros, reproduction, or the womb), 2) the sacred, and 3) death (Thanatos, destruction, or tomb), realms that have always been potential battlefields. I am inclined to call this constellation the eternal triangle of existential neuralgic points, able to trigger very negative sentiments, thoughts, and behavior toward imagery that people experience as transgressive, as well as toward its producers and their potential supporters.

As far as I can see, the most serious and intense controversies about art in the Western world in the last 150 years have been caused by transgressions (or the violation of more or less explicit taboos) in these three spheres. And it is my expectation that this will continue to be so in our ever more connected global world and its increasing religious and socio-cultural and -economic differentiation. Instead of presenting a long list of cases of »scandalous imagery« produced 
(on purpose or not) by a wide range of artists since 1850 , a detailing of the reactions to which would result in a boring déjà-vu, ${ }^{2 \mathrm{I}} \mathrm{I}$ prefer to specify the three neuralgic points - the fields of sex, the sacred, and death - as the fields that artists time and again use to produce imagery that not only disgusts members of particular groups and categories, but also spurs them to undertake something against it (from censorship to destruction).

The field of sex, Eros, and reproduction relates to human beings as well as animals and encompasses the following topics that have long inspired the fabrication of images that might easily lead to indignation: bestiality (Fig. 2), exhibitionism, nakedness, pedophilia, (child) pornography, prostitution, rape (Fig. 3), and sodomy. It is important to realize that the relevance of these subfields for creating imagery that might offend has not always been the same in time and place, but has fluctuated considerably, certainly in the Western world. Sieghart Ott formulated this nicely: »Added to this is that societal views of the proper and the offensive in the field of art constantly change, as history teaches. Even at the same time and in the same place, moral judgments and views are not unanimous. Namely, moral sensibility, as it normally and on the average dominates in broader swaths of the populace, is naturally shaped by various factors like disposition, descent, religion, upbringing, education, occupation, and personal experience. ${ }^{22}$ Take, for instance, naked children. Before 1975, the depiction of nude minors found few active objections in the US and Western Europe, but that changed rapidly thereafter $»$ when moral crusaders $[. .$.$] stormed the country to save the$ children< from alleged widespread sexual exploitation by perverts and pornographers. $\ll^{23}$ Ever since, there has been an increase in the number of scandals over the distribution and exhibition of paintings and photographs of naked youth. 


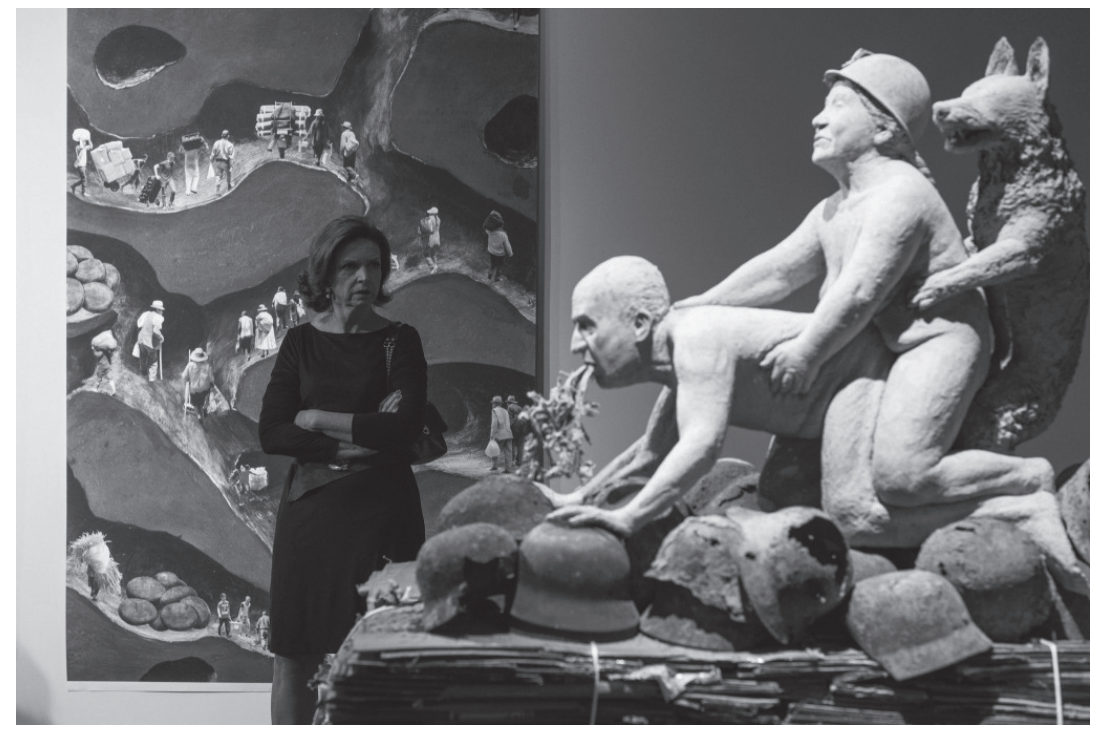

[FIG. 2]

Inez Doujak: Haute Couture 4. Transport, Barcelona Museum of Contemporary Art, Exhibition: La Bestia y el Soberano,

March I9-August 30, 2015

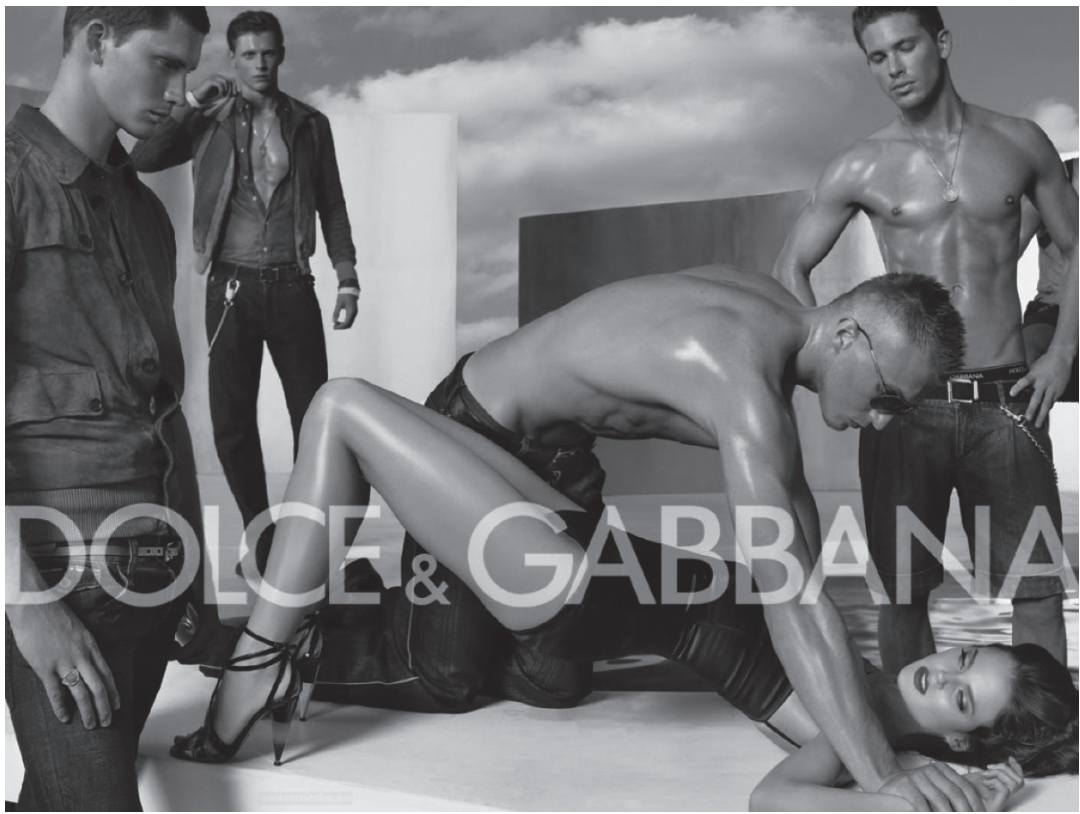

[FIG. 3]

Dolce \& Gabbana, 2007 
A very spectacular case involving the imagery of young naked girls deemed to be indecent occurred in Great Britain in October 2015. A London judge ruled that a great number of paintings and photographs of naked or partially naked children by the artist Graham Ovenden, who had been convicted of pedophilia a few years earlier, were not suitable for public or private view and therefore had to be destroyed. ${ }^{24}$ This is a remarkable example of an iconoclastic verdict by a judge that, however, is not without precedents. In 1912, for example, a similar sentence was passed on a (supposedly) obscene drawing by Egon Schiele. In this case, the judge himself carried out the destruction! Evers described this rather grotesque event: »The judge considers himself legitimated to burn a drawing by Schiele, and he does it in his judge's robe as if carrying out an act of justice, as if this act of vandalism were proof that the artist Schiele were in the wrong and that >morality< were on the side of the judge. $\ll^{25}$

The field of death, Thanatos, and destruction relates, like the first field, to both human beings and animals and encompasses the following phenomena that inspire artists to produce imagery with the potential to seriously hurt people's feelings: abortion, beheadings, body parts (Fig. 4), butchering (of animals), cadavers, cannibalism, corpses, dying or dead persons (Fig. 5), executions, genocide, laughter (in combination with the perpetration of physical violence), lynching, murder, mutilation, necrophilia, and torture. The potential of images pertaining to these and related subfields to cause upheaval and scandals also varies in time and place. What I find striking is that almost all scandals about imagery in these subfields, data about which I have collected since 1985, were connected with sculptures, photographs, posters, films, and artistic installations, such as the ones created by the British artist Damien Hirst, and not so 
much with other types of imagery, such as paintings, drawings, watercolors, etc. A special artistic genre containing imagery pertaining to several or even all these subfields is the horror movie, which is why certain groups (especially religious ones) have campaigned against the supposedly harmful content of this kind of film and for the introduction of regulations to prevent their uncensored showing as long as the medium itself has existed. ${ }^{26}$

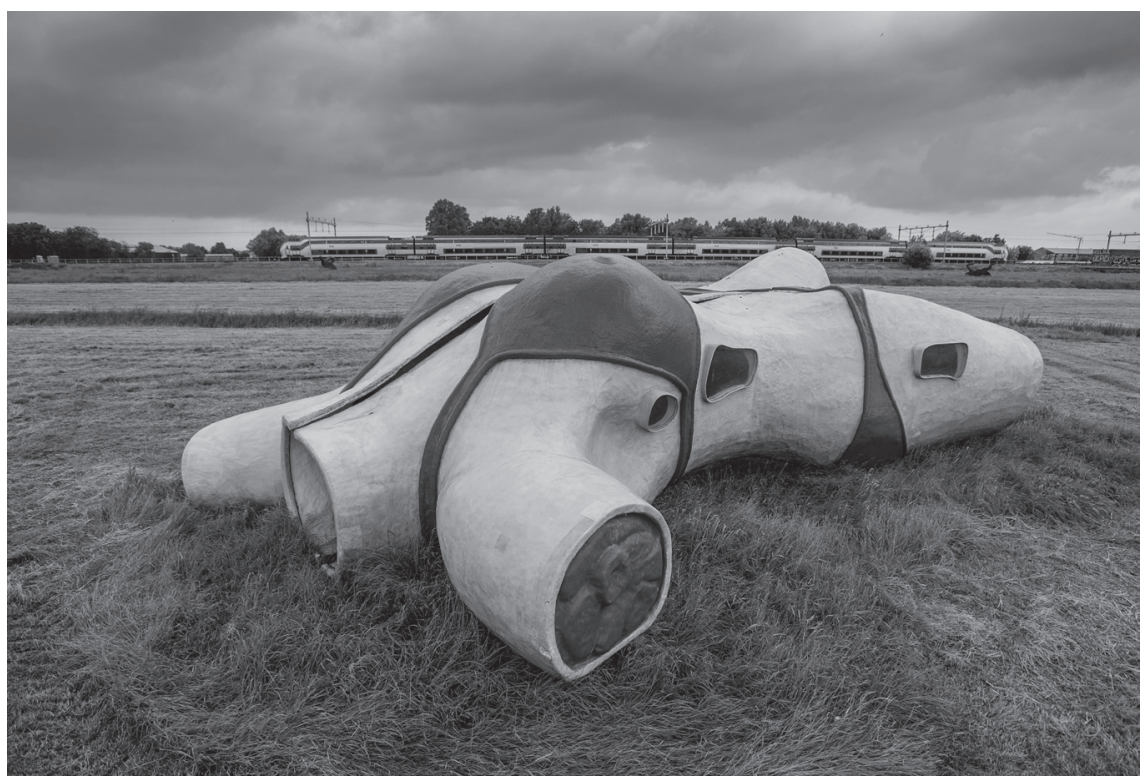

[FIG.4]

Atelier Van Lieshout: BikiniBar, 2006 (photo by Raymond

Rutting (C) 2014) 


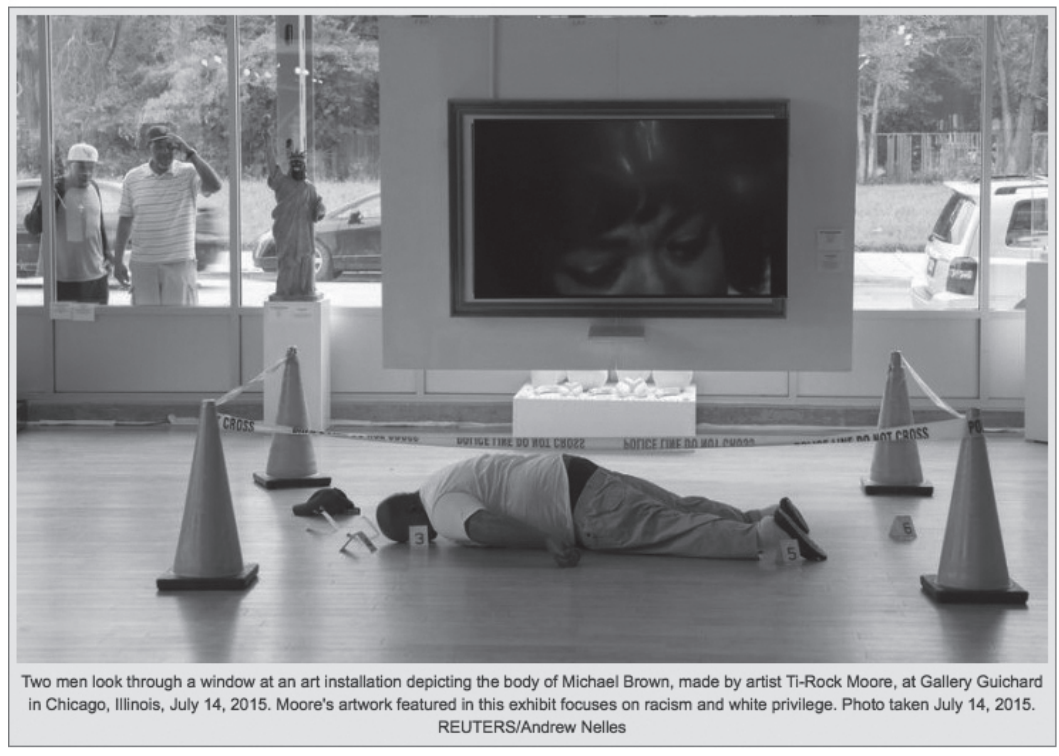

Chicago, IL - It was an image that shocked and angered many: a dead, black 18- year-old left face-down for hours in the middle of a street after being shot multiple times by a white police officer, his red Cardinals baseball cap knocked from his head by the fall.
[FIG. 5]

Ti-Rock Moore: Angelitos Negros, Gallery Guichard, Chicago, 2015

Since the field of the sacred, divine, and transcendental is crucial for all religions, it would be fair to at least briefly consider which subfields lend themselves to artists' production of blasphemous imagery, as perceived by the major world religions. Still, I will limit myself here to Christianity, in particular to specific subfields within this religion that are what one might call blasphemyprone. Though Christianity, just like Judaism and Islam, has rather strict interdictions against making images, ${ }^{27}$ it has a long history of depicting God the Father, the Holy Ghost, Jesus Christ, Mary, ${ }^{28}$ Joseph, the patriarchs, the prophets, and the disciples, as well as the Last Supper, the Crucifixion, and the Ascension.

In the last I5o years, it has been deviating depictions of God, (the birth and life of ) Jesus Christ, ${ }^{29}$ his crucifixion (Fig. 6), and the Last Supper that have been perceived as transgressive or blasphemous by certain categories of Christians 
and that have caused scandals in the Western world. $3^{\circ}$ Next in line were deviant representations of the rest of what I mentioned. I will pay no attention here to other forms of blasphemy or sacrilege that every now and then crop up with regard to specific Christian fields, themes, and topics. ${ }^{35}$ Though the temptation to present a series of notorious cases of blasphemy that have occurred since the end of World War II is great, I will merely mention that, in the postwar period, there has been a remarkable increase in what disgusted Christians regard as sacrilegious imagery of the crucifixion. Examples of offending art include Serrano's Piss Christ (1987), Martin Kippenberger's Der gekreuzigte Frosch (1990), the poster for the film The People vs. Larry Flint (1996) Bettina Rheims' cycle on the life ofJesus (1998), 32 Cornelius Kolig's Crucifixion in the Parliament of Carinthia (1998), Dorota Niezkalska’s Passion (2003), Vagritsch Bachtschanjan’s Sowjetischer Gekreuzigter (2007), Cosimo Cavallaro's chocolate sculpture My Sweet Lord (2007), and Paul Fryer's The Privilege of Dominion showing a gorilla on a cross (2009), as well as his Pietà showing Jesus sitting in an electric chair (2007) (Fig. 7).33

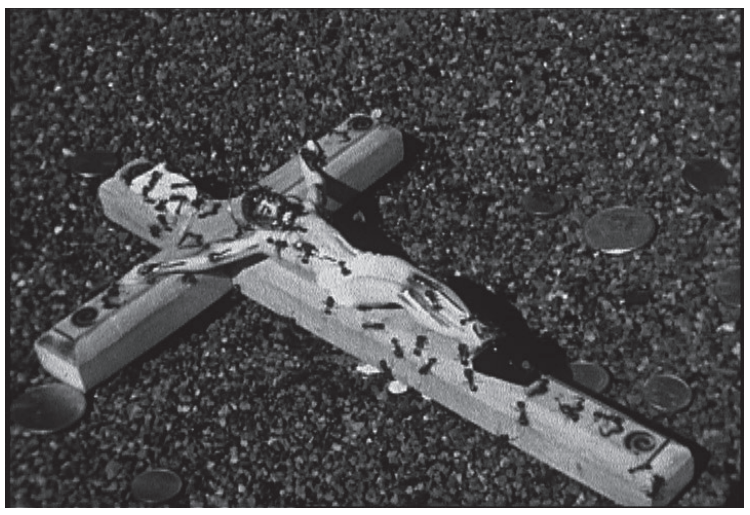

[FIG. 6]

David Wojnarowicz:

A Fire in My Belly (film still),

1986-1987, 2010 


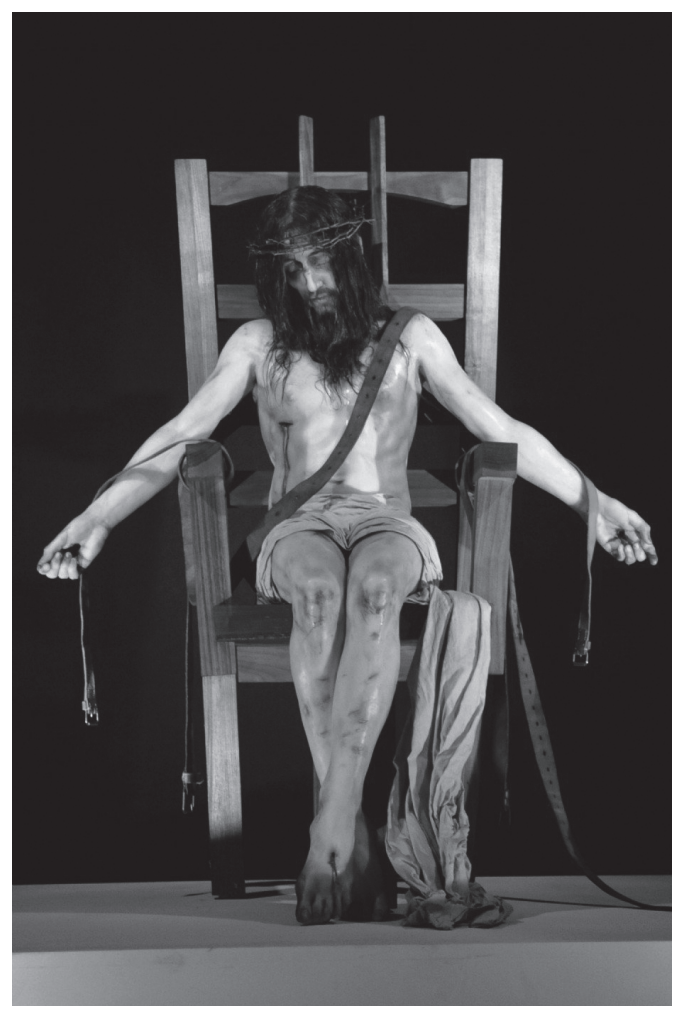

[FIG. 7]

Paul Fryer: Pietà (The

Empire Never Ended,

2007), Collection François

Pinault, exposed in the

Cathédrale Notre-Dame-

et-Saint-Arnoux, Gap,

France, April 2009

What strikes me is the fact that the number of similar transgressive images produced after World War II that remained unnoticed and/or did not trigger a scandal is considerably greater than the number of depictions that led to turmoil. The same holds true for similar imagery of the Last Supper. ${ }^{34} \mathrm{I}$ have the impression that the chance that a deviant and therefore potentially controversial depiction of this sacrament, as well as of the crucifixion, actually leads to a scandal is increased when it contains (an) erotic component(s). In general, deviant imagery that relates to not only one of the three fields mentioned, but to two or even to all three at the same time increases the possibility that it will generate disgust and the wish to get rid of it by a ban or even outright destruction..$^{35}$ 
This ends my brief elaboration of specific manifestations of what specific categories of consumers might experience as »aesthetic terrorism « by artists within the realms of Eros, Thanatos, and the sacred, together forming the eternal triangle of neuralgic points. ${ }^{36}$ In this connection, it is important to notice that there are more fields that artists might use as a source of inspiration for the fabrication of imagery that is contested and might lead to scandals, but I consider these to be less crucial. Think, for instance, of racist or discriminatory imagery, imagery of bodily matter out of place (such as blood, feces, vomit, saliva, sperm, urine, etc.), of disabled bodies, of taboo symbols or gestures (such as the swastika or Nazi salute), of permitted symbols in the wrong context, and of highly critical imagery of political or religious leaders (which they and their supporters sometimes experience as a sort of »lèse-majesté.«) The kind of strategies people who feel hurt and upset by taboo-violating imagery will adopt to get rid of it depends, of course, on the socio-political context they were raised in and are part of. In the Western world, they often approach the police and local magistrates with complaints and sometimes even go to court to make what they take as offensive imagery disappear from museums or the public sphere and/or try to persuade politicians to draft censorship laws. ${ }^{37}$ In extreme cases, they take their refuge in iconoclasm or worse. It is important to recognize that the kind of scandals treated in this essay almost always imply a dynamic sociological constellation of parties that shows a great family resemblance to the triadic figuration (of perpetrators, victims, and witnesses) that Riches described to better understand violence. ${ }^{38}$ 


\section{The parties involved, or the second triangle}

Scandals over images are human-made phenomena that, from a sociological perspective, involve at least three parties: the producer(s) of the imagery, the consumers who like it or take a neutral stand towards it, and the consumers who detest it. The producers sometimes, but not always, have the explicit intention to produce transgressive imagery that triggers negative reactions in consumers. Often the former do not have such intentions at all, and the latter feel offended, insulted, or hurt when confronted with artworks experienced as disgusting, obscene, and/or blasphemous. That is, if they are confronted with it at all; for a lot of what can be considered transgressive art remains fully unnoticed by the larger public, because it circulates only in specific museums and galleries, the so-called underground, and/or the crevices of the Internet. In this connection, it is important to realize that the context (for instance, a museum or the public sphere) in which imagery is shown can make a huge difference in response, negative, neutral, or positive. When certain consumers are moved by it in a positive way, then those who reject it almost always perceive them negatively as being just as corrupt, decadent, and depraved as its producers and their work. Doing research on scandals triggered by imagery thus always implies studying the classification and evaluation of this imagery by at least three categories: I) the producer(s) and their supporters who more or less like it, 2) the consumers who feel hurt by it in one way or another (the victims), and 3 ) the witnesses of their struggles (who might change sides over time). This sounds simple, but a study along these lines is not always easy to realize, especially when consumers who feel hurt themselves turn into makers of transgressive 
imagery, as happened, for instance, after the publication of the contested Muhammad cartoons in the Danish newspaper Jyllands-Posten in September 2005 . In this case, these cartoons triggered a real iconomachia ${ }^{39}$ or $»$ Bilderkrieg « between the »Christian « Western and the Muslim world, ${ }^{40}$ leading to violent demonstrations ending in death and destruction in several places. ${ }^{41}$ As a matter of fact, this image war had a predecessor in 2003, for after 9/In the Internet was intensively used to show a flood of anti- and pro-Bin Laden imagery, about which Birgit Richard wrote:

Unambiguous are $[. .$.$] the hate pictures in the Internet with which the$ opponents combat each other. On both sides, there are a vast number of hate pages that Neumann-Braun [...] characterizes as follows: lacking all moderation and any limit in regard to the humiliation and annihilation of the other. But the >de-normalization< he notes takes place on the $[\ldots]$ websites not on the linguistic, but explicitly on the pictorial level. ${ }^{42}$

This history repeated itself in January 2015 after a couple of angry young men murdered several editors of the satirical magazine Charlie Hebdo, because the editors had ignored several serious warnings to stop insulting the Prophet and his followers with words and images, and continued publishing cartoons of Muhammad that many Muslims all over the world deemed debunking and blasphemous. What's remarkable is that the sometimes utterly negative ways in which the Prophet is represented nowadays in imagery and otherwise in the Western world show a great family resemblance to representations of him in particular and Muslims in general as they already circulated among Christians 
in medieval times. For example, according to White, Muhammad figured in several medieval sources as a Christian heretic who was »thrown on a dung heap to be devoured by dogs and pigs ${ }^{43}$ and, according to Arjana, as a »demonic force, a human-animal hybrid, « in short, as a »Homo totus lubricus, a sexual monster. «44 We are confronted here with apparently age-old and stereotypical characterizations and representations used to disgust Muslim others. ${ }^{45}$

\section{Touching imagery, disgust, and rebounding violence}

Why is it that images can move people to become aggressive toward fellow human beings and things? Many scholars have already tried to answer this question. I do not believe that we will ever be able to adequately understand what viewers of taboo-violating art experience if we keep trying to make sense of it without taking the body seriously. The first thing we should realize is that our perception and experience of the world we live in cannot be understood if we continue to neglect the grounding of our knowledge-cum-affective-experience in the human body or more particularly the brain. If, moreover, we can accept that all our sensory experiences are ultimately tactile, then, I think, we might end up with a less spiritualistic and rational and more materialistic and therefore realistic interpretation of the »re-actions « of viewers to what they experience as disgusting and unsettling art. Elsewhere I have dealt extensively with the idea that we should reconsider the five-fold, hierarchical, Cartesian classification of our sensory experiences, for it blinds us to the fact that we relate to the world through the touch of the cornea of our eyes, of the tympanum 
in our ears, of the receptors in the mucous membrane in our nose, of the papillae on our tongue, of the sensors in our skin and/or our whole body, in short through at least five tactile sensations. ${ }^{46}$ The most important consequence of such a reconsideration of the old classification is that sight and seeing no longer are perceived as something mental and therefore distinct from touch and touching, but as specific forms of them. In this connection, it might be useful to pay more attention to what has lately been brought forward by cognitive scientists, who try to develop better insights into the role of embodiment in obtaining and using knowledge. ${ }^{47}$ For these scholars, humans are involved in a continuous process of storing, retrieving, and re-combining sensations, emotions, and knowledge in the body. Their approach can help to better understand why transgressive artistic imagery - that is, imagery characterized by an unconventional representation of, for instance, Eros, Thanatos, and the sacred as learned in specific socio-cultural settings - can generate an impressive multi-sensorial (aesthetic) positive, neutral, or negative experience..$^{4}$ The latter experience occurs mostly when people are faced with a formidable mismatch between the kind of imagery that they learned to incorporate in their bodies as acceptable and imagery in the outside world that is at loggerheads with this embodied imagery and by which they are touched. ${ }^{49}$ That this is an unsettling collision on a deep corporeal level, a disturbing process in the body, comes to the fore in the kind of language they use to express this experience. When they use expressions like »it hurts me« or »it is so disgusting that it makes me vomit, « this is not just metaphorical language, but language that hints at concrete, disrupting, fleshly experiences as a consequence of being touched by imagery outside the body that is entirely in opposition to imagery 
stored inside the body. One might speak here of a wound on a deep corporeal level or a physiological and/or neurological trauma. It seems that works of art that are experienced as offending and disgusting trigger a fundamental physical disturbance or - in other words - are felt as a violation of the physical integrity of a person or persons. ${ }^{50}$

I am trying to formulate a materialistic answer to the question of why imagery of a certain type has the power to move and motivate people in such a way that they want to get rid of this disgusting and sick-making material in one way or another to regain their physical (physiological and neurological) balance again. A remarkable thing in this connection is that curators of controversial exhibitions sometimes warn the visitors at the entrance with signs indicating that some works on display might generate unwelcome physical reactions. However, in the literature on scandalous art and disgusting imagery, this bodily dimension is generally not seriously addressed, whereas it seems to play a crucial role in triggering the kind of fierce and even violent reactions of specific viewers. But there are exceptions. ${ }^{5 \mathrm{I}}$ In her article on the uproar about the exhibition in 1997 of the artworks Piss Christ by Andres Serrano and Myra by Marcus Harvey, Alison Young ${ }^{52}$ comes close to the kind of perspective whose contours I have sketched in the foregoing section. For Young, as in my vision, disgust plays a crucial role, ${ }^{53}$ but she makes a wrong distinction between viscerally felt disgust, originating in skin contact with loathsome matter, on the one hand, and metaphorical disgust, i.e., disgust that only resembles physically felt disgust, triggered solely by seeing and not by actually touching a transgressive artwork, on the other. In my view, it is exactly the maintenance of this kind of distinction that stands 
in the way of developing a deeper understanding of the aggression of people after they are confronted with imagery that conflicts with the cherished imagery they learned to store in their bodies. It is a distinction immediately going back to our age-old classification of sensory modes that alienated the so-called higher ones - seeing and hearing - from their basically tactile grounding.

Though I disagree with Young's distinction between physical and metaphorical disgust, I like her concept »aesthetic vertigo", a phenomenon that she says pops up as the consequence of both the shrinking of the distance between a viewer and a controversial art work, so that real touching threatens to happen, and the growing consciousness that the artwork is but an image. However, I would »tactilize« the concept and connect it with the notion of »sensational« or »aesthetic form « as developed by Birgit Meyer. ${ }^{54}$ To eliminate this »aesthetic vertigo « triggered by exposure to imagery that is incongruous with the imagery they have learned to respect and idolize, people will do anything and as soon as possible, either through censorship or iconoclasm. Such radical reactions, in other words, are a direct consequence of people's constant use of specific corporeally internalized imaginative and normative formats as yardsticks to classify and evaluate all imagery that touches them through their senses and, especially, of mismatches between these formats and this imagery. Trying to persuade them with words and arguments to be tolerant, that is, to suppress their disgust or aversion, will seldom work, because they feel humiliated, insulted, and, more important in my view, hurt, injured, and wounded - in short, physically attacked. Instead of taking the peaceful road of tolerance, the offended react with what the anthropologist Maurice Bloch once called »rebounding violence, " that is, violence that is immediately triggered by violence done 
earlier to them.5 In this connection, I find Sherwood's comparison between the shocking texts and performances of prophets of the Old Testament and the shock art of the so-called Britart artists (for example, Damien Hirst, Chris Ofili, and Marc Quinn) and the reactions they trigger, such as »[...] censure, the cries of disapproval, separating the dignified, critical self from the degeneracy of the prophet/artist, ${ }^{56}$ interesting. But I deem even more important her observation that both the prophets and specific contemporary artists seem to court the sensation of »revulsion, even vomiting « and that the reflex of revulsion $»[\ldots]$ has to do with an instinctive reflex of self-preservation against sensations that act on the nervous system, that provoke a sviolent, dark revolt of being, and turn the subject sinside out.«\$7 Sherwood here refers to Kristeva's description of the horrific or the abject: »an extremely strong feeling which is at once somatic and symbolic, and which is above all a revolt of the person against an external menace from which one wants to keep oneself at a distance, but of which one has the impression that it is not only an external menace but that it may menace us from the inside. $\ll^{58}$

It is this revolt against a menace that people want to keep at a distance to stay not only physically, but also morally healthy that I find very relevant. However, one should never forget that the disgusting and the abject are ambivalent phenomena that not only trigger the wish to eliminate and chase them away, but that also exert a particular fascination on people, a strange desire to know more about them, as Carolyn Korsmeyer has extensively and convincingly shown in her fascinating study Savoring Disgust. 59 Imagery that upsets people in public spaces might be something they look for in the crevices of the Internet. In these pages, I have succinctly considered why confrontations with taboo- 
violating imagery in the fields of Eros, Thanatos, and the divine might so often lead to vehement reactions, especially negative ones. My tentative answer is that a deeper understanding depends on taking seriously the disrupting effects of the mismatch or iconoclash between external and internalized imagery in these fields on the level of individual bodies. This comes to the fore in the use of a specific corporeal language, or what I would like to call a »discourse of disgust, « to describe this particular tactile experience.

\section{Epilogue}

Instead of summarizing my findings and line of argumentation about socalled offending images, I prefer to conclude this essay by briefly dealing with two issues I did not touch upon so far, but which I deem relevant for broadening our understanding of the crucial role such images play in our world. First, I want to broach a dimension of transgressive imagery that leads us on to the field of the normative or the ethical and, second, I want to inquire whether we are heading for a future with fewer or more conflicts about controversial artworks and imagery.

During their socialization, human beings learn to store an immense amount of knowledge, rules, and regulations about adequate and proper behavior in their societies. Part of this cultural baggage consists of artistic and other imagery pertaining to the three fields of focus in this essay. Of course, there are differences in the character and size of this iconic reservoir, depending on such factors as education, class, gender, profession, and religion. But in general, the 
coming into existence, the growth, and the transformation of such a reservoir in individuals everywhere is based on an internalization of specific values or standards that are used to make distinctions in regard to, for example, aesthetic appreciation and normative or ethical acceptability. In other words, the incorporation of such values and standards involves people in a constant process of classification and evaluation of all kinds of imagery, and in its wake their rejection or more or less indifferent acceptance. In this context, it is important to remember the simple fact that the building up of iconic reservoirs cannot take place without the existence of imagery that is deemed unacceptable and therefore rejectable. Thus the accumulation of a specific corpus of images, for example religious ones, always implies, at least to a certain degree, the existence of unacceptable counterparts that one should avoid and exclude from incorporation, or even eradicate. The importance of antithetical imagery - often of an outspoken, transgressive nature - for the development of such a corpus or reservoir is proved by the existence of a wide range of genres in which it pops up, from films (especially horrorfilms) to fairy tales, myths, and stories in holy books (for example, the Bible and the Quran). In this regard, myths are very interesting because they often sketch deviant and disgusting ways in which gods and other supernatural beings behave toward each other and toward human beings, animals, and the world (and vice versa). Lévi-Strauss pointed out that the extreme behaviors and positions depicted in these stories " [...] are only imagined in order to show that they are untenable $«^{60}$ or - in the words of Bloch - »that mythology is often a speculation on practice, exploring all imaginable possibilities in what must remain an intellectual search. ${ }^{61}{ }^{6}$ The extreme positions and behaviors that myths show with regard to sex, violence, and even the sacred imply an invitation to their 
audiences to reflect on their ethical (un)tenability in the social context to which they belong. The same holds true for the other genres mentioned. One could even maintain that such genres, wherein all kinds of antithetic imagery figure, are part and parcel of all (sub-) cultures and that they are crucial for the more or less orderly and peaceful continuation of social life. Thus, the use of words or other means of depicting transgressions is not always experienced as offensive, but often more or less automatically related to its counterpart, that is, the aesthetically and ethically acceptable. What is striking here is that people can endorse and use antithetical imagery that they incorporated during their socialization to become and remain decent and at the same time be shocked by imagery created by others that clashes in a disgusting and unsettling way with the imagery they learned to accept in order to stay on specific moral and ethical tracks endorsed by their socialization. It is precisely physical imagery made by others that they want to eliminate as soon as possible in one way or another, because they are sensorially and intellectually attuned to different formats and feel hurt (and often also humiliated). What they often emphasize is the outrageous corrupting and depraving force this kind of transgressive imagery might trigger; it might lead to a dangerous, decadent, and distorted sort of society, so it should be removed, censored, or even destroyed immediately. ${ }^{62}$ Kieran Cashell says that the visceral, first reaction of the type »THIS IS WRONG: the artist was wrong to have done this« and »the artist's foul and loathsome work should immediately disappear« is often followed by an »ethical aftershock, « implying a kind of positive acceptance. Though this may happen in certain cases, I think that more often the contrary can be observed, that is, a stubborn clinging to the kind of imagery one has learned to cherish. ${ }^{63}$ This brings me to the second issue of this epilogue: 
whether we face a future with more or with fewer wars over artworks and imagery experienced as offensive.

I am pessimistic. The reason for my gloom is that, with the increasing social and cultural differentiation of societies all over the globe as a consequence of the increasing mobility and migration of people with different socio-cultural and religious backgrounds, on the one hand, and the increased speed with which technologically advanced media spread imagery around the globe, on the other, the chances will only increase that iconoclashes crop up time and again. An Islamophobic cartoon in an Icelandic newspaper might within hours spark a violent outburst in Pakistan, just as a deviant representation of Jesus by a German artist exhibited in New York might trigger anger and aggression among conservative Roman Catholics in the Us. The rapid dissemination of all kinds of imagery and people with different cultural backgrounds across the globe is and will be a very important source of global image wars now and in the near future. The call for freedom of speech and representation of, for instance, Eros, Thanatos, and the sacred asks for a kind of somatic tolerance, that is, a continuous repression or anesthesia of culturally bred and corporeally internalized aversions and appreciations that will not be easy to muster.

1 Thanks to Birgit Meyer and Christiane Kruse for their patience and critical, but always constructive, comments on earlier versions of this essay.

2 »Warburg war sich bewußt, daß dem immer neu zu form enden und schützenden Ich durch Bilder Unterstützungen, aber auch Verletzungen widerfahren können. Daß die Lebendigkeit des Bildes, mit der Möglichkeit des >Antuns< auch die Potenz zur Verwundung besitzt [...]«. Horst Bredekamp: Theorie des Bildakts, Berlin 20Io, p. 22.

3 See, for example, ibid. 
4 See Alison Young: Aesthetic Vertigo and the Jurisprudence of Disgust, in Law and Critique, II (2000), Pp. 24I-265 and Bruno Latour: What is Iconoclash? Or is There a World Beyond the Image Wars?, in Bruno Latour and Peter Weibel (eds.): Iconoclash. Beyond the Image Wars in Science, Religion, and Art, Karlsruhe and Cambridge/Mass. 2002.

5 See Henri Hubert and Marcel Mauss: Sacrifice. Its Nature and Function, trans. by W.D. Walls, London (I898) 1964.

6 Latour: Iconoclash, (see note 4), p. Is (emphasis JV). Though Latour without any doubt draws a parallel here between an iconoclastic act and bringing a sacrifice with the purpose emphasized by Hubert and Mauss, he refrains from working it out along the lines they sketch. More attention should be paid to their point that one cannot come close to the sacred, on the one hand, or reach a purified world, on the other, without committing a criminal act, that is, bringing a sacrifice.

7 See William J. T. Mitchell: What Do Pictures Want? The Lives and Loves of Images, Chicago 2005 .

8 See Ron Burnett: How Images Think, Cambridge/Mass., 2005

9 See Bredekamp: Theorie des Bildakts (see note 2).

10 See Jojada Verrips: The Thing Didn't »Do« What I Wanted. Some Notes on Modern Forms of Animism in Western Societies, in Jojada Verrips (ed.): Transactions. Essays in honor of Jeremy F. Boissevain, Amsterdam 1994, pp. 35-53.

11 Thus, my focus is not on idiosyncratic and/or highly individual acts of vandalism or iconoclasm against art. For this kind of reaction, see Marijke van Eeckhaut: Het moderne iconoclasme en andere verhalen. Een zicht op het onbekende, in Claire Vandamme and Francisca Vandepitte (eds.):
Hedendaagse Kunst en Vandalisme, Ghent 1998, pp. 41-53.

${ }^{12}$ Renée Steenbergen: Schock-Art. Zinloos geweld of zinvolle kunst, in CHIQ4 (1999), pp. 50-56.

13 See, for example, Eduard Fuchs: Geschichte der erotischen Kunst. Erweiterung und Neubearbeitung des Werkes »Das erotische Element in der Karikatur« mit Einschluß der ernsten Kunst, Berlin 1908; Sieghart Ott: Kunst und Staat. Der Künstler zwischen Freiheit und Zensur, Munich 1968; and Jean-Claude Bologne: Nacktheit und Pruderie. Eine Geschichte des Schamgefühls, trans. from the French by Rainer von Savigny and Thorsten Schmidt, Weimar 2001, pp. 229-272.

14 They came to my notice through Beth Irwin Lewis, who deals with the first and the third of these cases in the prologue of her book and with the second in Chapter I. See Beth Irwin Lewis: Art for All? The Collision of Modern Art and the Public in Late-Nineteenth Century Germany, Princeton and Oxford 2003, pp. 8-13, 48-52.

15 \#Die furchterregende Darstellung erhielt einen pornographischen Ort und stand gleichzeitig im Zentrum der Aufmerksamkeit«. Liliane Weissberg: Monkey Business, in Kunstforum, II4(I99I), p. 239.

16 »In Wahrheit sind derartige Themen eines so reifen Talents nicht würdig, und die Jury hat recht daran getan, diese häßliche und dramatische Figurengruppe abzulehnen». Quoted in ibid., p. 237

17 See Irwin Lewis: Art for All? (see note I4), p. 8.

18 Though I could have chosen other scandals triggered by art works (for example, Édouard Manet's Déjeuner sur l'berbe or Thomas Eakins's The Swimming Hole) in the second half of the igth century as prototypical, I preferred the scandal over 
Frémiet's sculpture, because it touched upon an issue that was in the air: the interrelation among species. For the scandals over Manet and Eakin, see, respectively, Jan Dunlop: Kunst die de Wereld Schokte, Bussum 1972 and Jennifer Doyle: Sex Objects Art and the Dialectics of Desire, Minneapolis 2006 .

19 »[...] es gewagt hat, seinen christlichen Mitbürgern solche Verhöhnung ihres Heilands öffentlich ins Gesicht zu schleudern« by having painted him as »den häßlichsten, naseweisen Juden-Jungen, den man sich denken kann«. Martin Faass and Henrike Mund: Sturm der Entrüstung. Kunstkritik, Presse und öffentliche Diskussion, in Martin Faass (ed.): Der JesusSkandal. Ein Liebermann-Bild im Kreuzfeuer der Kritik. Berlin 2009, pp. 67-68.

${ }^{20}$ See Irwin Lewis: Art for All? (see note 14), Princeton and Oxford 2003, p. I2.

${ }^{21}$ To get an impression of imagery that has been experienced as scandalous see, for instance, Walter Böckmann (ed.): Kunst vor dem Richter. Was ist Kunst - und wann ist Kunst obszön? in Littera Dokumente - Berichte - Kommentare, 4 (1964); Sieghart Ott: Kunst und Staat. Der Künstler zwischen Freiheit und Zensur, Munich 1968; Siegfried Salzmann: Im Namen des Volkes. Das "gesunde Volksempfinden«als Kunstmaßstab, Duisburg 1979; Steven C. Dubin: Arresting Images. Impolite Art and Uncivil Actions, London and New York 1992; Sabine Fellner: Kunstskandal! Die besten Nestbeschmutzer der letzten I59 Jahre, Vienna 1997; Heinz Peter Schwerfel: Kunst-Skandale. Über Tabu und Skandal, Verdammung und Verehrung zeitgenössischer Kunst, Cologne 2000; Peter Zimmermann/Sabine Schaschl: Skandal. Kunst, Vienna 2000; Anja Zimmermann: Skandalöse Bilder-Skandalöse Körper. Abject Art vom Surrealismus bis zu den Culture Wars, Berlin 200I; Anthony Julius: Transgressions. The Offenses of Art, London 2002; Jürgen Raap: Abendmahl, in Kunstforum, I60 (2002a), pp.
90-96; Jürgen Raap: Kannibalismus, in Kunstforum, 160 (2002b), pp. 204-209; Jürgen Raap: Tabus, in Kunstforum, I60 (2002c), pp. 267-272; K. Vandenabeele/K. Vermeir(ed.): Transgressie in de kunst, in Jaarboek voor Esthetica, 2004; S. Brent Plate: Blasphemy. Art That Offends, London 2006; Kerstin Mey: Art \& Obscenity, London and New York 2006; George Petros: Art that Kills. A Panoramic Portrait of Aesthetic Terrorism 1984-200I, n.p. 2007; Demetrio Paparoni: ERETICA. The Transcendent and the Profane in Contemporary Art, Milan 2007; Ute Schüler / Rita E. Täuber: Skandal: Kunst! Schockierend - packend visionary, Stuttgart 2008; Kieran Cashell: Aftershock. The Ethics of Contemporary Transgressive Art, London and New York 2009; Kathrin Linder: Kunstskandale Heute: zwischen Trivialität und Relevanz, Lizentiatsarbeit at the University of Zurich 20ı0; Thomas Schlesser: Lart face à la censure. Cinq siècles d'interdits et de résistances, Paris zoII; Elea Baucheron / Diane Routex: Skandalkunst. Zensiert. Verboten. Geächtet, Munich 2013; Bettina Papenburg and Marta Zarzycka (eds.): Carnal Aesthetics: Transgressive Imagery and Feminist Politics, London and New York 2013; Dagmar Fenner: Was kann und darf Kunst? Ein ethischer Grundriss, Frankfurt on the Main and New York 2013. Also interesting in this connection are the websites of the Virtual Museum of Offending Arts and Censorship: http://www.kwetsendekunst.nl/ and http://www.zensurarchiv.de/index.php?title=Kunst (accessed on Feb. 2, 2017), for both sites offer neat overviews of controversial art.

22 "Hinzu kommt, daß die gesellschaftlichen Anschauungen über das auf dem Gebiete der Kunst Schickliche und Anstößige sich - wie die Geschichte lehrt - ständig wandeln. Selbst zur gleichen Zeit und Ort sind moralische Wertungen und Anschauungen nicht einhellig. Das sittliche Empfinden, wie es normal und durchschnittlich breitere Volkskreise beherrscht, wird nämlich naturgemäß bestimmt durch verschiedene Faktoren wie Anlage, Herkunft, Religion, Erziehung, Bildung, Beruf oder persönliches Erleben.» 
See Ott: Kunst und Staat (see note 13), p. 130; cf. Fuchs: Geschichte der erotischen Kunst (see note 13), p. 74.

${ }^{23}$ See Lawrence A. Stanley: Art and »Perversion«-Censoring Images of Nude Children, in Perspektief(Quarterly Photography) Magazine, 40 (1991), p. I2.

${ }^{24}$ Cf. https://news.artnet.com/graham-ovenden-photos-destroyed-339976 (accessed on Feb. 2, 2017).

25 „Der Richter hält sich für berechtigt, eine Zeichnung von Schiele zu verbrennen, und er tut es im Talar, als vollziehe er einen Akt der Gerechtigkeit, als sei durch diesen Akt des Vandalismus erwiesen, daß der Künstler Schiele Unrecht habe und >die Morak auf Seiten des Richters sei«. See Hans Gerhard Evers: Kunstverbote durch Sittengerichte, in Walter Böckmann: Kunst vor dem Richter (see note 2I), p. 68.

${ }^{26}$ See Jojada Verrips: The State and the Empire of Evil, in Paul Clough / Jon P. Mitchell (eds.): Powers of Good and Evil. Social Transformation and Popular Belief, New York and Oxford 2001, pp. 185-210.

${ }^{27}$ See Ex. 34:I3, 17 and Deut. I2:2. For Islam and images, see Richard Ettinghausen: Arabische Malerei, Geneva 1962, pp. II-I7, and for Judaism and images, see Anthony Julius: Idolizing Pictures: Idolatry, Iconoclasm and Jewish Art, New York 200I.

${ }^{28}$ A very interesting case of a deviant or transgressive representation of Our Lady or la Virgin de Guadalupe that triggered protest rallies and even death threats addressed to its maker (the artist Alma López, a Mexican-born Chicana) occurred in Mexico in 20or. See Alicia Gaspar de Alba / Alma López (eds.): Our Lady of Controversy. Alma López's »Irreverent Apparition«, Austin 20II.

${ }^{29}$ An example of imagery regarding the life of Jesus that caus- ed much turmoil was the photographs of the Savior »among homosexuals, trans people, leather people and people with AIDS « by the Swedish photographer Elisabeth Ohlson Wallin, shown in the exhibition Ecce Homo, which toured in Europe between 1998 and 2004. See Gabriella Ahlström: Ecce Homo. Berättelsen om en utställning, Stockholm 1999 and http://en.wkipedia.org/wiki/Ecce_Homo_(exhibition) (accessed on Feb. 2, 2017).

${ }^{30}$ In this connection, see Nissan N. Perez: Corpus Christi. Christusdarstellungen in der Fotografie, Heidelberg 2003.

${ }^{31}$ For an enlightening overview of sacrilege and blasphemy, see Martin Scharfe: Über die Religion. Glaube und Zweifel in der Volkskultur, Cologne 2004, Pp. 157-207. See Yvonne Sherwood: Biblical Blaspheming. Trials of the Sacred for a Secular Age, Cambridge 2012, p. 74, for the ways in which not only the God of the Old Testament, but also His prophets often engaged in blasphemy toward other gods (since they were »regularly reduced to mere material, blocks of wood, or submerged in an acid bath of satire « and »parodied in distortions of their names [...] or reduced to snothings, sabominations or pieces of dung or shit.«)

32 The female crucifixion is not unknown in the Roman Catholic Church, for Saint Wilgefortis, a bearded woman, was nailed to a cross. Whereas her image became part of its saintly tradition, this cannot be said of the many, often highly eroticized and therefore controversial images of crucified women made by artists from I850 on. See Jürgen Zänker: Crucifixae. Frauen am Kreuz, Berlin 1998. See also Anne-Marie Korte in this volume.

${ }^{33}$ It is important to realize that the image of Jesus on the cross is increasingly used to demand attention for other forms of human (and even animal) suffering, for example at the exhibition Cross Purposes: Sbock and Contemplation in Images of the Crucifixion in London, 2010. For uncontested images of 
Christ in modern art, see Richard Harries: The Image of Christ in Modern Art, Farnham 2013.

${ }^{34}$ See Jürgen Raap: Abendmahl (see note 2I).

35 Along with the three neuralgic points a, b, and c, the triangle also implies the following combinations: $\mathrm{a}$ and $\mathrm{b}$, $\mathrm{a}$ and $\mathrm{c}, \mathrm{b}$ and c, and, finally, a, b, and c. My data gave me the strong impression that imagery in which both Eros and the sacred are connected in a deviant way (for example, in the work of the Belgian artist Felicien Rops and recently in a series of scabrous cartoons of the Prophet by a host of cartoonists) is considered extremely disgusting and therefore ripe for censorship or iconoclasm.

${ }^{36}$ In 2000 , the Museum Boijmans Van Beuningen Rotterdam organized an exhibition with the title Exorcism / Aestbetic Terrorism that showed work by such artists as Louise Bourgeois and Bruce Naumann, who, according to Sütö, tried to take seriously the expression: "To strangle the devil, one has to look him in the face.« See Wilma Sütö: Exorcism/Aesthetic Terrorism, in Wilma Sütö and Bas Heijne: Exorcism Aesthetic Terrorism. Fiery temperaments in contemporary art, Rotterdam 2000, p. 27. See also Petros: Art that Kills (see note 2I), p. 9 .

37 See, for example, Marjorie Heins: Sex, Sin, and Blasphemy. A Guide to America's Censorship Wars, New York 1993 and Young: Aesthetic Vertigo (see note 4).

${ }^{38}$ See David Riches: The Phenomenon of Violence, in David Riches (ed.): The Anthropology of Violence, Oxford 1986 , pp. I-28.

${ }^{39}$ For the term iconomachia, see Costas Douzinas / Lynda Nead (eds.): Law and the Image. The Authority of Art and the Aesthetics of Law, Chicago 1999.
${ }^{40}$ See Ursula Baatz et al.: Bilderstreit: Pressefreiheit? Blasphemie? Globale Politik?, Vienna 2006.

${ }^{41}$ In September 20I5, exactly ten years after the Muhammad cartoons appeared in the Jyllands-Posten, there was again a lot of discussion in Denmark about these controversial images that led to many deaths and injuries in the world, because the Conservative People's Party pleaded for their insertion in schoolbooks, so that the schoolchildren might become acquainted with them.

42 „Eindeutig sind $[\ldots]$ die Hassbilder im Internet mit denen sich die Gegner bekämpfen. Auf beiden Seiten gibt es eine Unzahl von Hatepages, die Neumann-Braun [...] folgendermaßen charakterisiert: ohne jedes Maß und Grenze, was die Erniedrigung und die Vernichtung des Anderen angeht. Die vom ihm konstatierte $>$ Ent-Normierung findet bei den [...] Websites aber nicht auf sprachlichen, sondern explizit auf der bildlichen Ebene statt.« See Birgit Richard: 9-II. World Trade Center Image Complex + »shifting image, « in Kunstforum, $164(2003)$, pp. 37-74.

43 See David Gordon White: Myths of the Dog-Man, Chicago and London 1991, p. 67.

${ }^{44}$ See Sophia Rose Arjana: Muslims in the Western Imagination, Oxford 2015, p. 32. For »survivals« of the representation of the Prophet and Muslims as horny and lecherous beings, see, for example, several of the cartoons by Luz (Rénald Luzier) published in the controversial journal Charlie Hebdo, https://www.les-crises.fr/charlie-a-manipule-la-france/ (accessed on Feb. 2, 2017).

${ }^{45}$ Muslims in medieval times used the same kind of negative stereotypes to characterize Christians. Cf. White: Myths (see note 43 ), p. 67.

${ }^{46}$ See Jojada Verrips: Aisthesis \& An-Aesthesia, in Orvar 
Löfgren / Richard Wilk (eds.): Off the Edge. Experiments in Cultural Analysis, Copenhagen 2006, pp. 29-37.

47 See Cyril Pennartz: Athenes ademtocht. De neurale codering van emotie, herinnering en bewustzijn, Amsterdam 2003.

${ }^{48} \mathrm{~A}$ fine example of a thought-provoking approach in art appreciation that takes the body, more particularly the cognitive unconscious (perceived as all multisensory and neural processing), seriously is the one developed by Joy and Sherry. See Annamma Joy / John F. Sherry Jr.: Speaking of Art as Embodied Imagination. A Multisensory Approach to Understanding Aesthetic Experience, in Journal of Consumer Research, 30 (2003), pp. 259-283.

49 The incorporated imagery is reminiscent of Adolf Göller's concept of the »Gedächtnisbild« or »memory image«, by which he meant »the image of something that we slowly build up in our memory after repeated viewings. « See John Onians: Neuroarthistory. From Aristotle and Pliny to Baxandall and Zeki, New Haven and London 2003, p. IIo.

${ }^{50}$ See Jojada Verrips: Offending Art and the Sense of Touch, in Material Religion, 4(2) (2008), pp. 204-225.

51 Plohman, for example, wrote an interesting thesis on how, at the end of the $20^{\text {th }}$ century, artists, such as Thorneycroft, began to stir the emotion of disgust in museums - formerly quiet, clean places that emphasized just watching and having an aesthetic experience - by exhibiting disturbing imagery of deviant nudity, sex, and death. "The fact that disgust is tied into many bodily sensations and emotional responses or memories, «she writes, »promises that art works that purposefully employ the disgust tactic will transform the body in the museum space.« See Angela Plohman: ReThinking Contemporary Aesthetic Spaces. Diana Thorneycroft and the Unacceptable Sublime, unpublished thesis in the Department of Art History, Montreal 2000, p. $27-28$.
${ }^{52}$ See Young: Aesthetic Vertigo (see note 4).

${ }^{53}$ Miller calls disgust an emotion, that is, a feeling »connected to ideas, perceptions, and cognitions and to the social and cultural contexts in which it makes sense to have those feelings and ideas « and often a motive for action. See William Ian Miller: The Anatomy of Disgust, Cambridge/Mass. 1997, pp. $7-8$.

54 See Birgit Meyer: Mediation and the Genesis of Presence. Towards a Material Approach to Religion, Utrecht 2012.

55 See Maurice Bloch: Prey into Hunter. The Politics of Religious Experience, Cambridge 1992. Bloch claims that this process in which the victim of violence turns into a perpetrator is often the outcome of (religious) rituals in which the participants are put through acts of symbolic violence, such as bodily mutilations. The »prey, «so to speak, is transformed into a »hunter.« David Pope's cartoon »He Drew First, "showing a masked man who just shot a cartoonist, which Australia's Foreign Minister presented to the Paris office of Charlie Hebdo in April 2015, illustrates this radical reversal perfectly; see http://www.abc.net.au/news/20r504-21/autralian-cartoonis-makes-a-mark-on-charlie-hebdo/ 6409180 (accessed on Feb. 2, 20I7).

${ }^{56}$ See Sherwood: Biblical Blaspheming (see note 3I), p.I65-66.

57 Ibid., p. I70.

${ }^{58}$ Kristeva cited in Plohman: Re-Thinking Contemporary Aesthetic Spaces (see note 5I), p. 40.

${ }^{59}$ See Carolyn Korsmeyer: Savoring Disgust. The Foul \& the Fair in Aesthetics, Oxford 2orr. See also Miller: The Anatomy of Disgust (see note 53), p. 22. Schiller already dealt extensively with the ambivalent character of what disgusts, for example, in his texts Gedanken über den Gebrauch des Gemeinen und Niedrigen in der Kunst and Zerstreute Betracbtungen 
über verscbiedene ästhetische Gegenstände. See Wolfgang Riedel (ed.): Friedrich Schiller. Sämtliche Werke. Vol. V. Munich and Vienna 2004, pp. 537-570.

${ }^{60}$ See Claude Lévi-Strauss: The Story of Asdiwal, in Edmund Leach (ed.): The Structural Study of Myth and Totemism, London 1967, p. 30.

${ }^{61}$ See Bloch: Prey into Hunter (see note 55), p. 99.

${ }^{62}$ Compare this with what Winfried Mennninghaus main tained in an announcement of a lecture in the IFK on 3 December 2012 titled Was heisst es, sich von einem Kunstwerk »bewegt« zu fühlen?, namely that »die Bewertung eines Kunstwerks als bewegend tendenziell durchweg eine positive genuin ästhetische Bewertung impliziert.« As if he, who published a fascinating study on disgust, had never heard of transgressive or taboo-violating art and the sort of unpleasant, negative emotions this kind of art might generate in many people. But he did, for the lecture contains a section on "Abject Art, « in which he is scornful about this sort of art, because in his view, it is true of the disgusting »daß es als maximaler Gegenwert des Schönen und stärkster anti-ästhetischer Reiz nicht ein für allemal den Sieg über die Idealisierung der Form davon tragen kann.«So, abject art concerns just beautifully designed provocations and nothing else! See Winfried Menninghaus: Ekel. Theorie und Geschichte einer starken Empfindung, Frankfurt on the Main 2002, p. 567.

${ }^{63}$ See Cashell: Aftershock (see note 2I), p. I2. 